\title{
MAPPING OF THE NORTH-EASTERN PART OF KOZLOWICKA BURIED VALLEY BASED ON GEOELECTRICAL DATA
}

\author{
Sylwia Topolewska, Marcin Stępień, Sebastian Kowalczyk \\ Faculty of Geology, University of Warsaw, ul. Żwirki i Wigury 93, 02-089 Warszawa, Poland, \\ e-mails: stopolewska@gmail.com,marcin.stepien@uw.edu.pl; s.kowalczyk@uw.edu.pl
}

\begin{abstract}
The paper is aiming to determinate the extent of the northeastern arm of Kozłowicka buried valley on the grounds of own research by means of electrical resistivity tomography - ERT and available archival researches. On the Hydrogeological map of Poland, Żyrardów sheet (Felter and Nowicki, 1998a, b) Kozłowicka buried valley was differentiated as an individual hydrogeological unit. The results of the analysis show that the extent of the structure, defined by its upper boundary, differs significantly from the one suggested on the sheet of Hydrogeological map of Poland. Since there was no data available in the northeastern part of the discussed arm of Kozłowicka buried valley, the northern boundary was defined only based on available geoelectrical sounding profiles (Czerwińska, 1988; Topolewska, 2015). In order to confirm suggested solution, geoelectrical research by means of electrical resistivity tomography (ERT) was conducted. The measurements were performed along 3 profiles located in the area of interest. The authors would like to point out the need of the usage of ERT in mapping and studying buried structures that might be groundwater reservoirs. As a result, one obtains quasi-continuous image of electrical resistivity of the subsurface. Due to the contrast of electrical properties of sediments, it is possible to determine upper and bottom surfaces of buried structures, formed within glacial deposits.
\end{abstract}

Key words: buried valley, geoelectrical methods, electrical resistivity tomography, ERT

Manuscript received 28 April 2016, accepted 17 October 2016

\section{INTRODUCTION}

Geoeletrical methods, based on a physical property of the subsurface - electrical resistivity, might be used successfully to determine the extent of buried structures (Black et al., 1962; Smith, 1974; Ahmad and Schmitt, 2005, Topolewska, 2015). Electrical resistivity is a physical parameter that enables to distinguish lithologies within geological medium (Białostocki and Farbisz, 2007; Farbisz et al., 2010; Palacky, 1987; Saleh and Samsudin, 2013). However, electrical resistivity obtained during measurements does not indicate unambiguously type of sediment or soil, because it depends on many different factors: inter aliamineral composition (especially, in the presence of clay minerals), structural and textural characteristics (porosity, particles cementation, compaction), water presence and its conductibility. Buried valleys are structures that were created during two phases. First, concave structure was created by river or stream, and then in the second phase, it was filled up with fluvial, glaciofluvial or lacustrine material in several sedimentation cycles during interglacials or after complete deglaciation, thereafter covered by younger sediments. In West Mazovian, area that is scarce in water of passable quality, this type of Quaternary structures might be potential source of water supply (Felter and Nowicki, 2003). Kozłowicka buried valley is one of them. It was described and mapped for the first time by Felter and Nowicki (1998a, b) on. Hydrogeological map of Poland (MhP), sheet Żyrardów. The aim of this paper is to verify by means of ERT the upper boundary of the northeastern arm of Kozłowicka buried valley which was determinated by Topolewska (2015) on the grounds of own and archival VES (vertical electrical sounding) studies (Czerwińska, 1988). As a result, resistivity maps were created. They show how the extent of the valley changes with depth.

\section{AREA DESCRIPTION}

\section{Location}

The research area was limited to the northeastern arm of Kozłowicka buried valley. It is located in the southwestern part of Mazovian Province (Fig.1) within Grodzisk County (circa $30 \mathrm{~km}$ west from Warsaw). Hydrogeologically, it is located entirely within groundwater body ${ }^{1}$ number 65 , accord- 


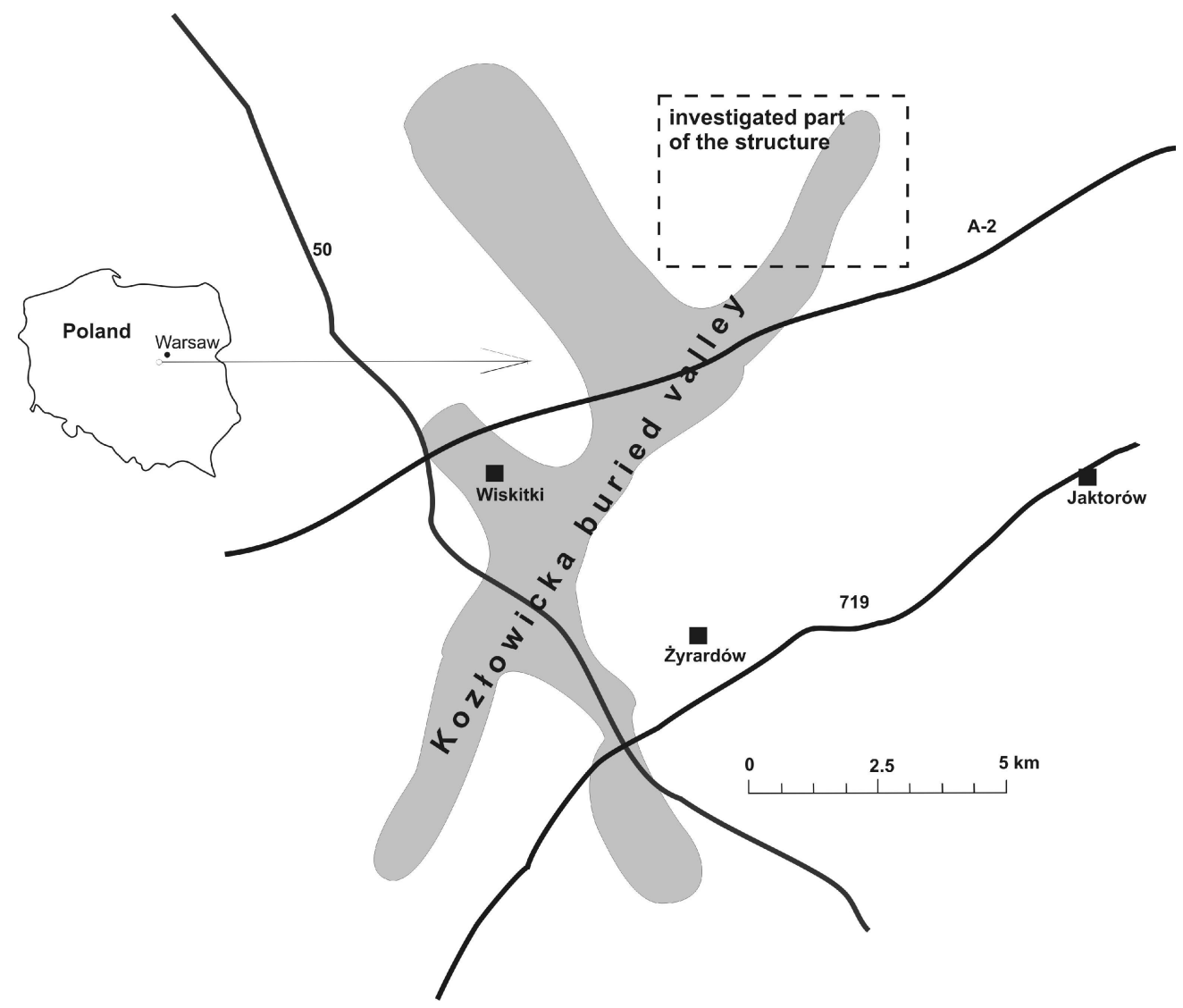

Fig. 1. Location of the study area with Kozłowicka buried valley according to Felter and Nowicki (1998b). Black lines - main roads; A-2, 50,719 - numbering of main roads; black arrow - indication of the structure on the map of Poland, grey-colored area - Kozłowicka buried valley, dashed-line polygon - investigated part of the structure, black squares - bigger cities in the area.

ing to division into 172 parts effective from 2016 and within another hydrogeological unit or groundwater basin ${ }^{2}$ number 215a called Subniecka warszawska (Herbich et al., 2007).

According to the physiographic regionalization of Poland (Kondracki, 2009), the research area is located within province Middle European Plain and subprovince Central European Lowlands. It is located in macroregion Central Mazovian Plainand in mezoregion Łowicko-Błońska Plain (Fig. 2). Locally, altitude differences reach few meters and are produced by fluvial erosion processes. Northern and northwestern parts of the sheet Żyrardów (research area included), Łowicko-Błońska Plain, are quite flat. The altitudes drop slightly towards the north and the northwest (Felter and Nowicki, 1998a, b). Kozłowicka buried valley is not visible in the morphology.

\section{Geology}

Kozłowicka buried valley is located in the northwestern part of a geological structure called Mazovian Basin. It is a concave structure in the Cretaceous sediments basement that is overlain by thick layers of Paleogene-Neogene and Quaternary sediments. Few geological boreholes, located in Żyrardów and Sochaczew, documented upper boundary of Cretaceous sediments at $193-197.5 \mathrm{~m}$ below the surface. The most crucial for this research are Pleistocene sediments. Geology will be described on the grounds of the geological cross-section presented in the figure 3 . The location of the cross-section line is shown on a geological map of the northeastern arm of Kozłowicka buried valley in figure 4. Description of geology and geological map of the research area were based on information given by Geological detailed map of Poland Żyrardów sheet (Szalewicz, 1993). Stratigraphic division of Quaternary suggested by Różycki (1972) and used by Szalewicz was updated using the latest.

The oldest deposits on the cross-section are dated to Pliocene. They are lacustrine sediments, mainly clays and clays with silt (Fig. 3; layer 1). They were encountered at the bottom of three out of four boreholes that were used to make the cross-section - at around $60 \mathrm{~m}$ a.s.l. at the extremes of the line and at around $27 \mathrm{~m}$ a.s.l. in the central part of the sequence. As it is shown on the cross-section, they might have been once a continuous layer. Analysis of nearby boreholes showed that thickness of those sediments is $45-48 \mathrm{~m}$. In one borehole, complex of sand, gravel and residual gravel dated to South Polish Glaciations was encountered at $66 \mathrm{~m}$ a.s.1. (layer 2a). It is $6 \mathrm{~m}$ thick. It has not been detected in other geological profiles. In two middle boreholes, at 48 and $54 \mathrm{~m}$ a.s.l. a complex composed of fluvial sands and gravels (2b) was encountered. Its maximum, documented thickness rea- 
ches $26 \mathrm{~m}$ in a borehole no. 5570117. Those sediments constitute the filling of a buried valley (believed to be a part of Kozłowicka buried valley), deeply cut into the Pliocene substrate, with axis direction SW-NE. It was dated to Podlasian Interglacial (or Małopolska Interglacial according to Różycki, 1972). In a borehole no. 5570118, varved clay (3a) was encountered at two levels, first at around $63 \mathrm{~m}$ and then at $71 \mathrm{~m}$ a.s.1. In the same borehole, till (3b) was encountered at $65.6 \mathrm{~m}, 75.6 \mathrm{~m}$ and $81.6 \mathrm{~m}$ a.s.l. Between youngest layers of till, 2-meters thick layer of clay and silt (3c) was detected. Their thickness varies between 2 and $6 \mathrm{~m}$. In a borehole no. 5570108 , till (3b) was encountered at $72.3 \mathrm{~m}$ a.s.1. and its thickness is $7 \mathrm{~m}$. This deposit was thought to be a continuation of tills on the western part of the cross-section. The oldest sediments aged (4) to Middle Polish Glaciation, were encountered in all four boreholes. In the middle ones, they reach greater depths. Their maximum thickness is around $35 \mathrm{~m}$. Bottom part (4a) is built of lacustrine fine sands. Top part (4b), in turn, seems to be of even finer fraction. They are clay and silt and silty sand. It is possible that top part of complex 4, clay and silt might be the same layer as clay and silt (3c) in the west. Then they could also have created a separate layer that has no relation to the buried valley. However, it appears that the top boundary of the buried valley on most resistivity models is encountered much closer to the surface.They were deposited during Odranian Glaciation (according to Różycki, 1980) or during Krznanian Glaciation (according to Lindner and Marks, 1999), which indicate more or less same age (Lindner and Marks, 2012).This lithologically diversified complex together with a complex of fluvial sediments $(2 b)$ is believed to constitute the filling of Kozłowicka buried valley.

A continuous complex of tills (5), in WSW part, was encountered at around $88 \mathrm{~m}$ a.s.l. while in ENE part - at around $94 \mathrm{~m}$ a.s.1.. Its thickness varies from 6 to $16 \mathrm{~m}$. In a borehole no. 5570117, thin layer of residual gravel and boulders (6) was encountered at $86 \mathrm{~m}$ a.s.l. Silt and clay (7a) were encountered in a borehole no. 5570144 at $92 \mathrm{~m}$ a.s.l. They constitute also a thin layer. Sediments common on the surface are tills (7b) that were found in most of the profiles. Their thickness maximally reaches $16 \mathrm{~m}$. They were the last deposit dated to Middle Polish Glaciation (Warta Stage, according to Lindner and Marks 2012) that was determined in this area. Humic sands and peat (14) dated to Holocene were detected in one borehole. They are usually at bottom of river valleys or depressions. They are often encountered on tills (7b) and on lacustrine sediments (7a).

The genesis of the structure seems to be double. It was suggested by Topolewska (2015) that the structure involved two complexes, bottom one ( $2 b)$ that consisted of fluvial deposits (sand and gravel) dated to Podlasian Interglacial and upper one (4a-b) composed of lacustrine deposits (clay, silty sand, fine sand) dated to Krznanian Glaciation. Though, it is not sure if these complexes are actually separated by sediments from Sanian1 Glaciation (layers $3 \mathrm{a}-\mathrm{c}$ ).

\section{Hydrogeogeology}

Due to the capacity of sediments to store water, Kozłowicka buried structure is one of the most important hydrogeological units in the area. Overlying tills seems to be good

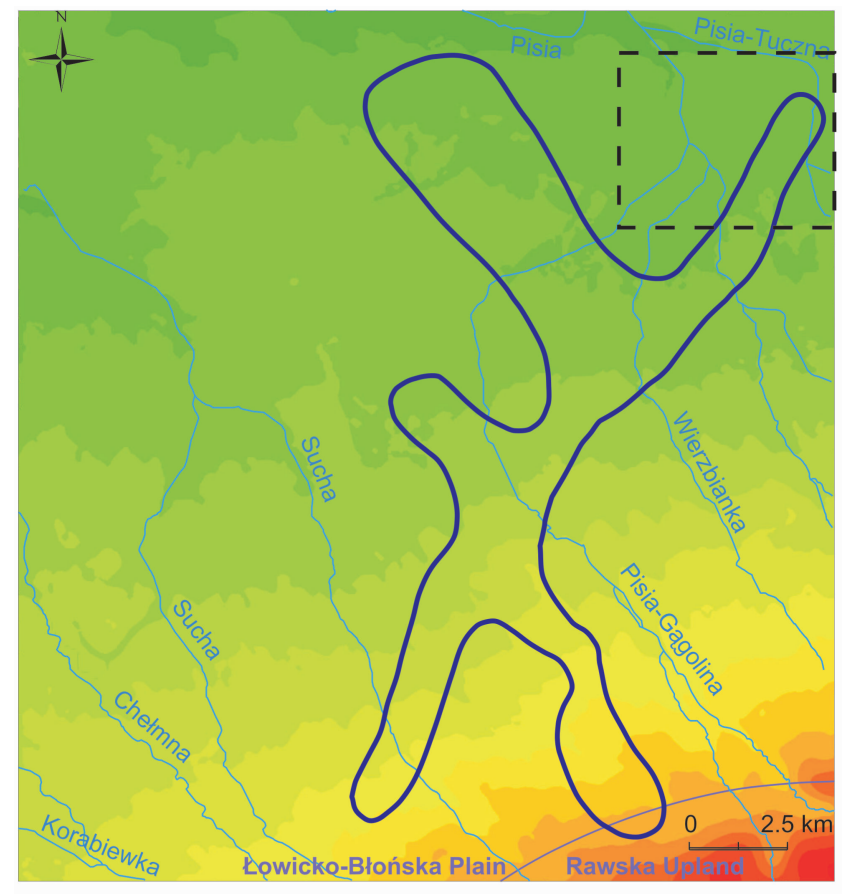

Altitude [m a.s.I.]

$8590 \quad 95100105110115120125130135140145150155160165$

$$
\begin{aligned}
& \text { Kozłowicka buried valley } \\
& \text { (according to the sheet of }-- \text { investigated part of } \\
& \text { MhP (557) Żyrardów I _ _ the structure } \\
& \text { river }
\end{aligned}
$$

Fig. 2. Location of Kozłowicka buried valley on the hypsometric map of the region (557) Żyrardów (Felter and Nowicki, 1998b).

enough to isolate the water-bearing structure underneath, still it is characterized by poor or no isolation. According to Balcerkiewicz (1989) and Wysocki (1996), hydrogeodynamic parameters determinated for the whole complex of sediments of Kozłowicka buried valley are following: hydraulic conductivity varies from 5 to $44 \mathrm{~m} / \mathrm{d}$ (16 m/d on average), transmissivity locally is above $1000 \mathrm{~m}^{2} / \mathrm{d}$, potential discharge of wells ranges from 70 to $120 \mathrm{~m}^{3} / \mathrm{h}$ and disposable resources

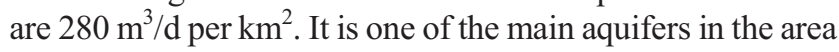
and was determined as a separate hydrogeological unit.

\section{FORMER STUDIES}

Topolewska (2015) gathered all the relevant information on Kozłowicka buried structure, having analyzed former researches and added results and conclusions from her own study. She based her research mainly on Czerwińska's geoelectrical (VES) studies (1988) which aimed to explore northeastern part of the structure that was believed to be a good groundwater resource. The results were reinterpreted and presented in the form of geoelectrical cross-sections that showed resistivity distribution in the subsurface. This way, it became possible to determinate the extent of the upper boundary of the buried valley. Hydrogeological map of Poland by Felter and Nowicki (1998a,b) was one of the main ar- 


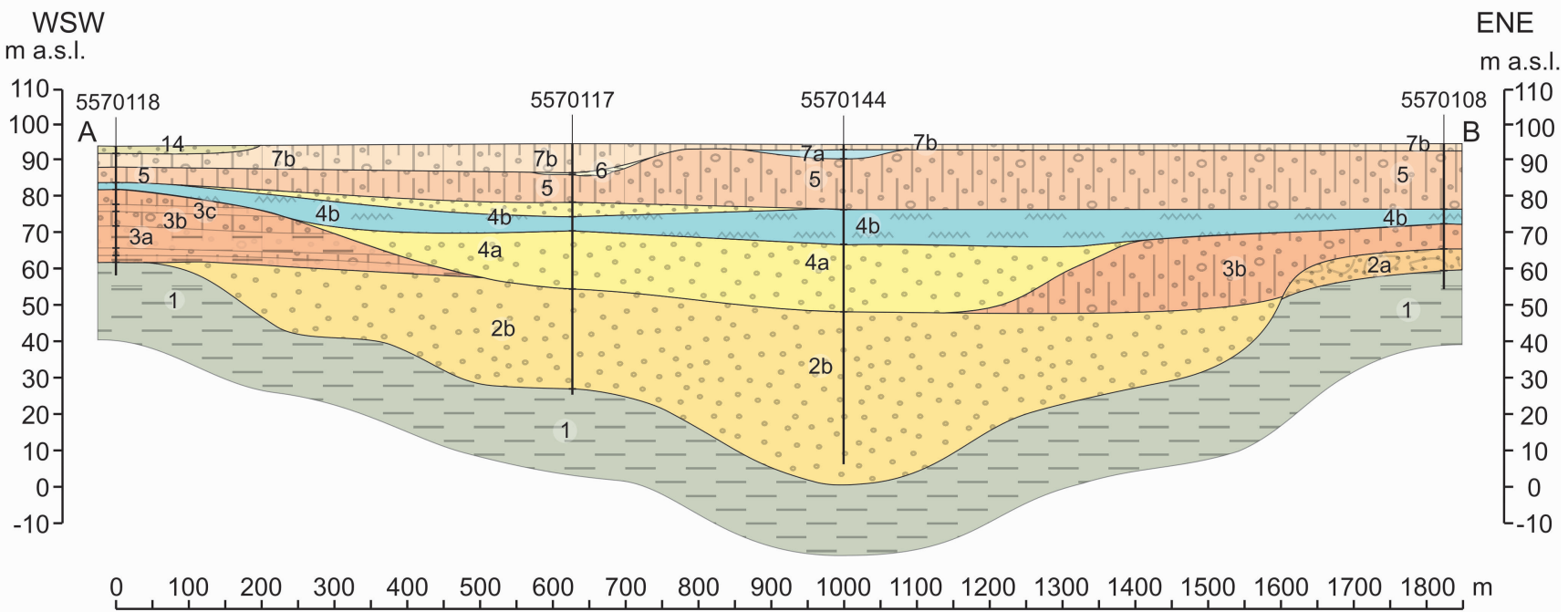

\section{Legend}

Sediments divided according to

lithology (colors and numbers) and stratigraphy

\begin{tabular}{|c|c|}
\hline 14 & humic sand \\
\hline $7 b$ & till \\
\hline $7 a$ & silt and clay \\
\hline 6 & residual gravel and boulders \\
\hline 5 & till \\
\hline $4 b$ & $\begin{array}{l}\text { lacustrine clay, silt and clay, } \\
\text { fine sand }\end{array}$ \\
\hline $4 a$ & lacustrine fine sand \\
\hline $3 c$ & clay and silt \\
\hline $3 b$ & till \\
\hline $3 a$ & varved clay \\
\hline $2 b$ & fluvial sand and gravel \\
\hline $2 a$ & $\begin{array}{l}\text { residual fine, medium and coarse } \\
\text { sand with gravel and boulders }\end{array}$ \\
\hline
\end{tabular}

1 clay

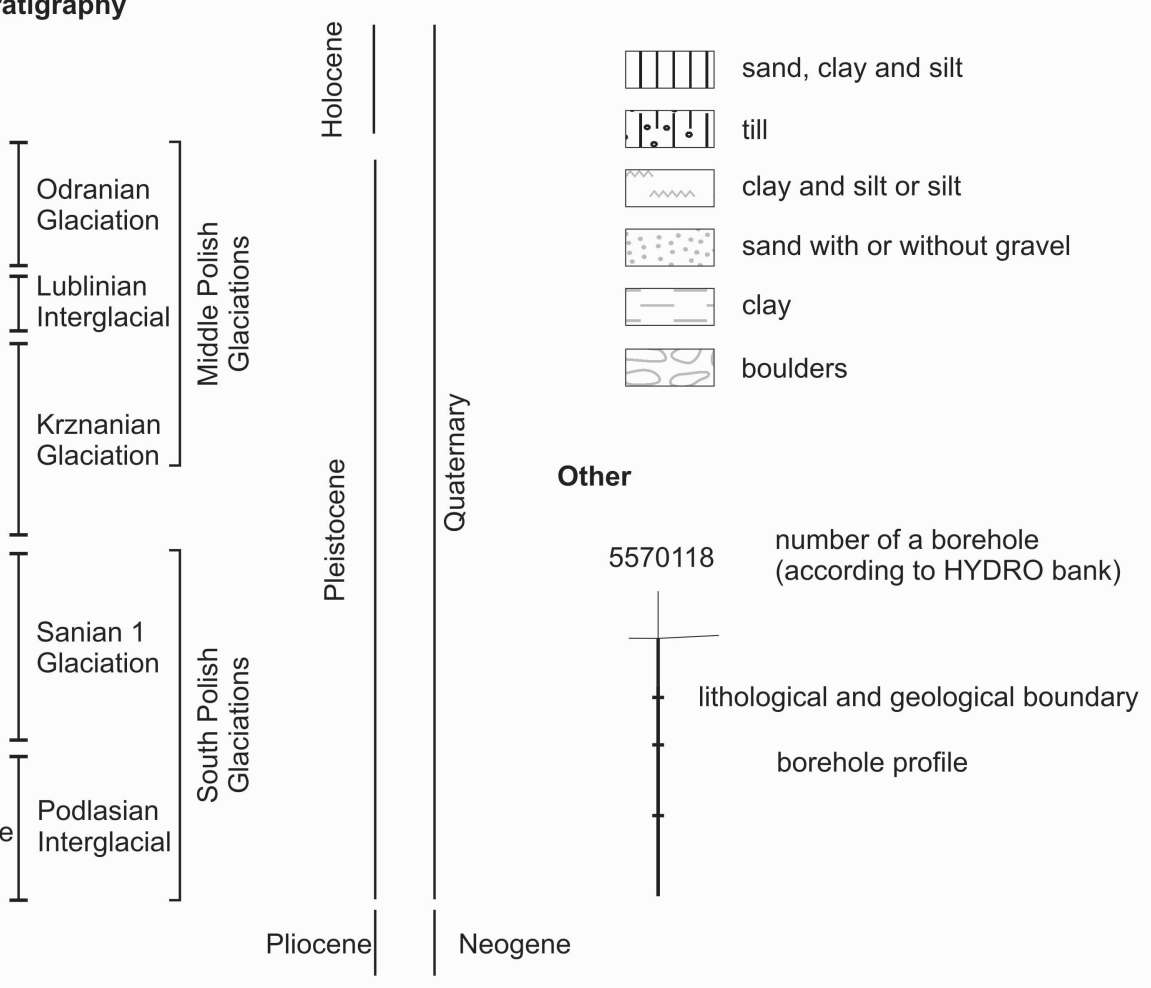

Fig. 3. Geological cross-section along profile line A-B (Topolewska, 2015; with slight changes).

chival studies that Topolewska (2015) used as a base for her own research. However, just at the beginning of the analysis she observed that the extent of Kozłowicka buried structure proposed by the authors could not be correlated with the geoelectrical studies of Czerwińska (1988) that were believed to be the most essential base for this part of the map. Topolewska suggested the location of a new (upper) boundary of the structure where eastern and western boundaries were determined based on reinterpreted archival VES research (Czerwińska, 1988) and her own ERT measurements. Due to the lack of data, she could not determine the exact location of southern and northern boundaries. This paper de- scribes the results from the study carried out at the site where northern and western boundaries of the northeastern arm of Kozłowicka buried valley were supposed to be situated.

\section{METHODS}

Since the aim of the research was to determine the location of the boundary of Kozłowicka buried valley, structure filled up with highly resistive sediments within low resistive deposits, geoelectrical methods were most suitable. Electrical resistivity tomography (ERT) was used. Electrical resistivity tomography method (term used i.a. by Zhou et al., 
2001; Kemna et al., 2002; Zhou et al., 2002; Daily et al., 2004) is also called electrical resistivity imaging (ERI) (term used i.a. by Van Schoor, 2002; Loke and Lane, 2004; Smith and Sjogren, 2006; Ratnakumari et al., 2012) or continuous vertical electrical sounding (CVES) (term used i.a. Van Overmeeren and Ritsema, 1988; Chongoa et al., 2011; Aning et al., 2014). Principles of resistivity electrical methods, their application and foregoing development were described i.a. by Dahlin (1996), Loke et al. (2013), Samouëlian et al. (2005).

ERT measurement was performed by means of Terrameter LS, product of Swedish company ABEM. Along 4 cables, 21 electrodes were placed with the spacing of $5 \mathrm{~m}$ at each cable. Since the profile lines were longer than $400 \mathrm{~m}$, roll-along technic was applied with a gradient array, as described in detail by Dahlin and Zhou (2006). The usage of this array usually enables to notice changes in resistivity whenever horizontal or vertical lithological boundaries are crossed. In order to get closer to the target, which was determination of the extent of the valley, ERT was applied along three profiles. In contrast to VES, it gives a two-dimensional insight into the subsurface - in vertical and horizontal directions. The results were interpreted and presented in the form of resistivity models (Figs 6, 7). They were put together with archival results (achieved by the means of ERT and VES) and presented in the form of resistivity maps made at different altitudes (Fig. 8).

\section{RESULTS}

Measurements were performed along 3 profiles. The location of the profiles is shown on a documentation map (Fig. 5). They are marked with black lines. In addition, profile 1 was also plotted on the geological map (Fig. 4). Others were unfortunately situated beyond its limits. The profiles were situated in a way so that the western (profile 1) and northeastern (profile 2 and 3 ) boundaries of the structure (determined on the grounds of archival ERT and VES studies; light brown line on the documentation map) could be crossed. Measurements along profiles CVES 1 and CVES 2, also present on the maps (Figs 4, 5), were done as a part of a different study (Topolewska, 2015) and were presented in this paper, since they were thought to bring essential information. The results are presented on 3 resistivity models (Fig. 6). Additionally, resistivity models along CVES 1 and CVES 2 were described (Fig. 7).

In figure 6 , three resistivity models are presented. Measurement along profiles 1-3 were performed in June and July 2015. On models, three resistivity complexes were identified: highly resistive with higher than $75 \Omega \mathrm{m}$ (light green, yellow, orange, red), moderately resistive with resistivity range from 30 to $75 \Omega \mathrm{m}$ (blue/green) and low resistive with values lower than $30 \Omega \mathrm{m}$ (blue).

Along profile 1, highly resistive sediments (sands) constituting the filling of the valley were encountered in the southeastern part of the profile line reaching depths of around 50 meters all the way towards the border till approximately 250 meters from the starting point of the profile where their bottom boundary was found around 40 meters below the surface. Even though, some sediments with resistivity of

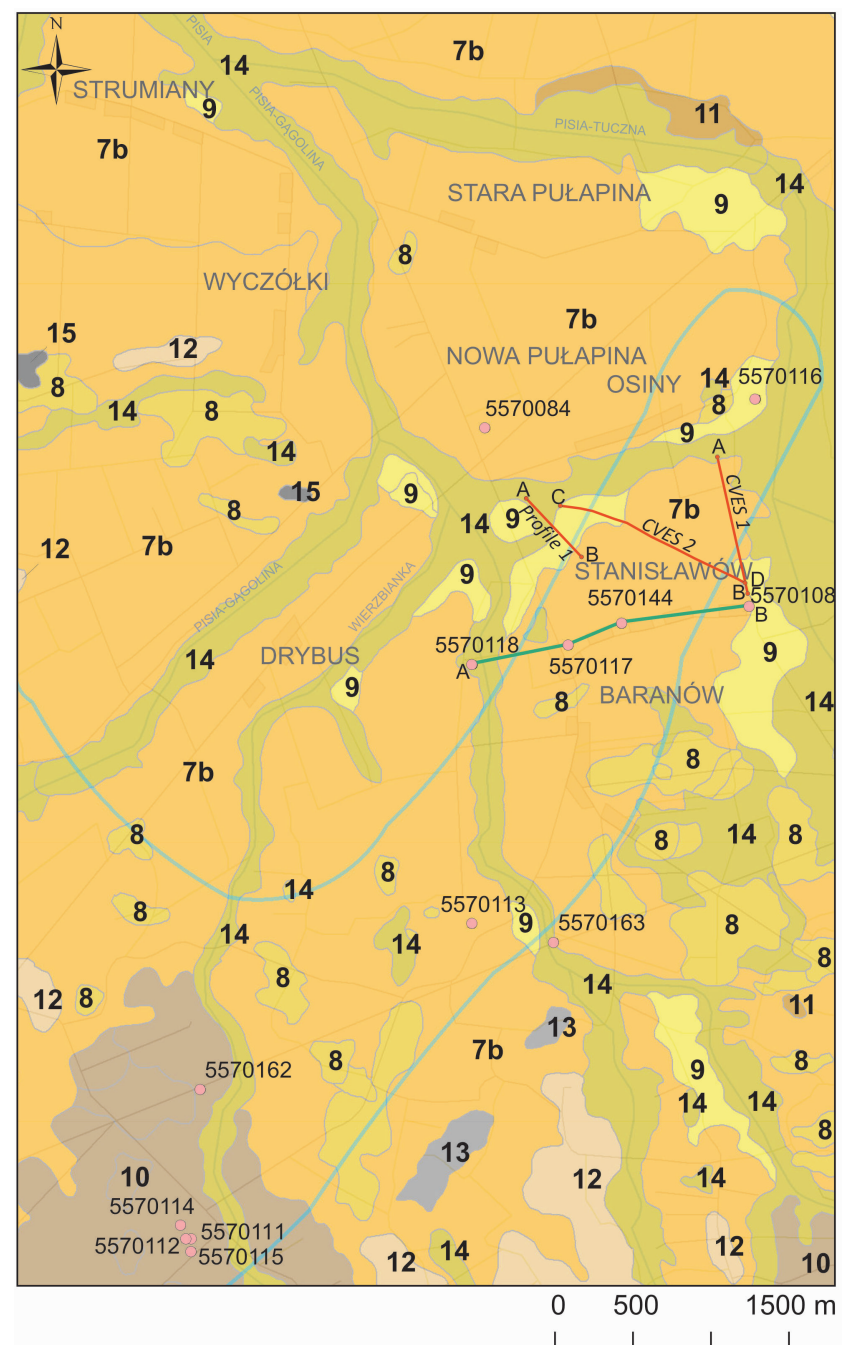

\section{Legend}

15 peat, peaty sediments $\quad 10$ alluvial sand with gravel

14 humic sands

9 fluvial sand and gravel

13 gyttja, peat, clay and silt, sand (lacustrine sediments)

8 fluvioglacial sand with gravel

12 eluvial sand derived from till

7b till (Odranian Glaciation)

1 diluvial sand, grave, silt and clay

upper boundary of Kozłowicka buried valley according to the sheet of MhP (557) Żyrardów

5570084 hydrogeological borehole (numbering according to HYDRO bank)

geological cross-section line

$\stackrel{\text { CVES } 2}{\mathrm{C}}$ CVES profile line roads

Fig. 4. Geological map of investigation area (Topolewska, 2015). Numbering corresponds to numbering on geological cross-section in figure 3 .

around $70 \Omega \mathrm{m}$ (probably tills) appear at the northwestern extreme of the profile, it is believed that the valley does not continue westwards. There is a low resistive elongated area present at $250-550 \mathrm{~m}$ from the first electrode that is reaching 


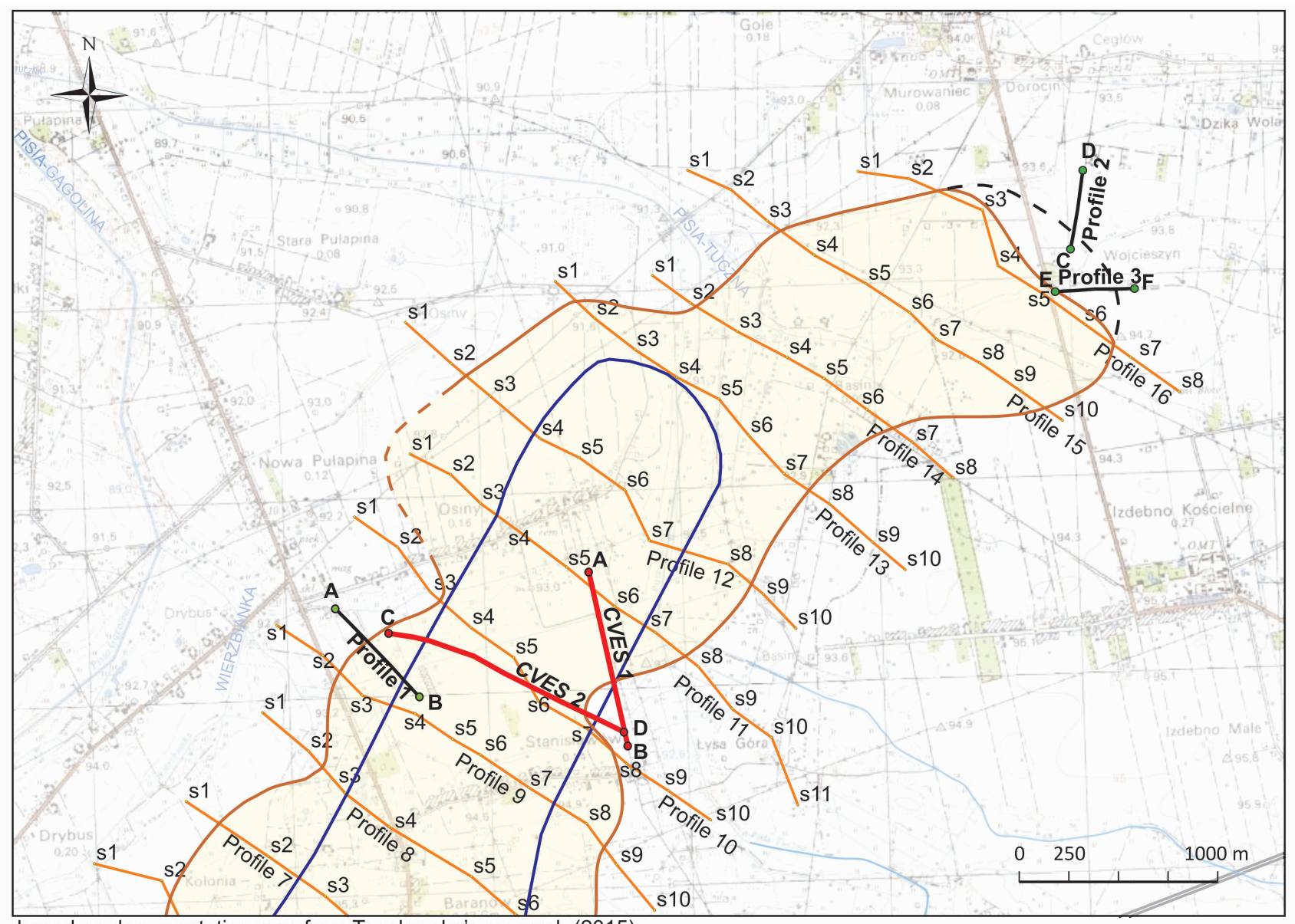

based on documentation map from Topolewska's research (2015)

Legend

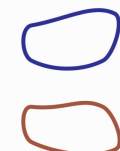

upper boundary of Kozłowicka buried valley (according to Felter and Nowicki, 1998b)

upper boundary of Kozłowicka buried valley (according to ERT and VES researches)

$c-1$
$2-1$
$2-1$

probable route of upper boundary of Kozłowicka buried valley (needs to be verified in the future)

$\frac{\text { Profile } 10}{\mathrm{~s} 9}$

incorrect route of upper boundary of Kozłowicka buried valley (verified by new ERT measurements)

COCVES 2

VES profile line and VES point (Czerwińska, 1988 with new numbering)

ERT profile line (Topolewska, 2015)

A Profile 1 new ERT profile line

highway A2

Fig. 5. Documentation map of ERT and new ERT profiles with reinterpreted VES survey (Czerwińska, 1988) based on documentation map from Topolewska's research (2015).

depths of 5 meters. Based on information revealed by geological profiles, those are most likely tills. Underneath the valley, at around $60 \mathrm{~m}$ a.s.1. in the northwestern part and at around $45 \mathrm{~m}$ a.s.l. in the southeastern part,sediments with resistivities lower than $25 \Omega \mathrm{m}$ are located. They are believed to be Pliocene clays. If we look at geological cross-section (Fig. 3), upper boundary of Pliocene clays is also located at $60 \mathrm{~m}$ a.s.l. on both ends of the profile line.

Those results enabled to replace probable contour of the boundary (marked with a dashed line) in the western part of the structure (Fig. 5) with a confirmed one (marked with a continuous line). Most of the sediments along profile 2 represent low resistivities $(<40 \Omega \mathrm{m})$. They might be either clays with additive of sediments with higher resistivities as tills or sands or more probably tills or tills with additive of clays. There is one spot with higher resistivity $(40-60 \Omega \mathrm{m})$ that stretches from 80 to $100 \mathrm{~m}$ (horizontally) and from 85 to $70 \mathrm{~m}$ a.s.l. (vertically). It might be a sand lens with lower than usual resistivity. It can be explained in a way that it was affected on edges by the sediments from the surroundings with lower resistivities.

The sediments along profile 3 represent mostly low 


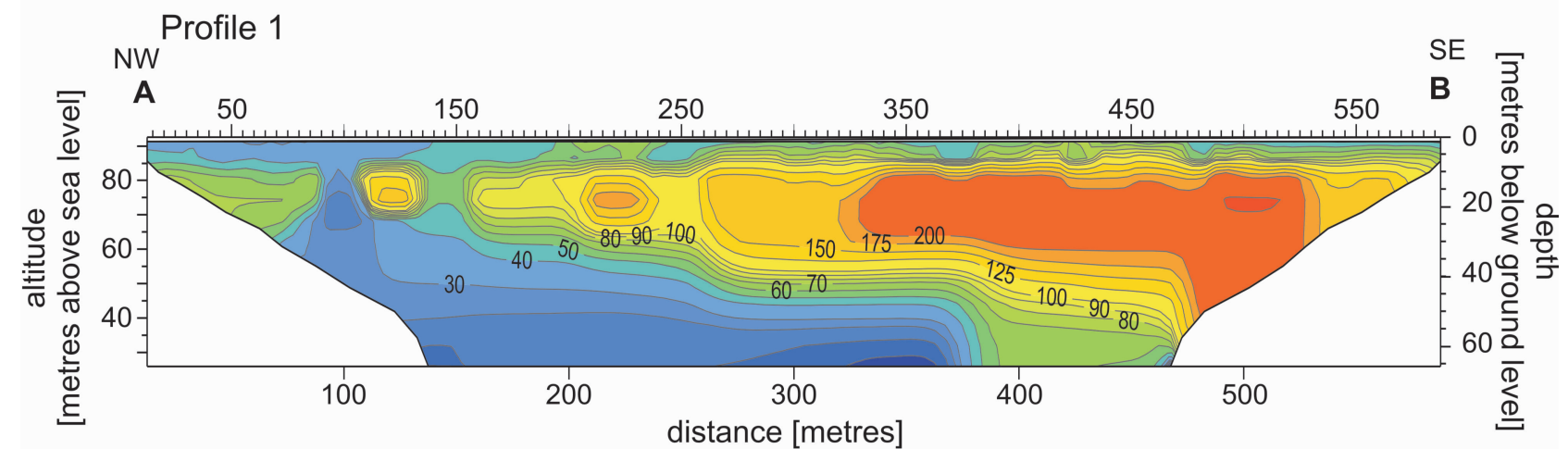

Profile 2

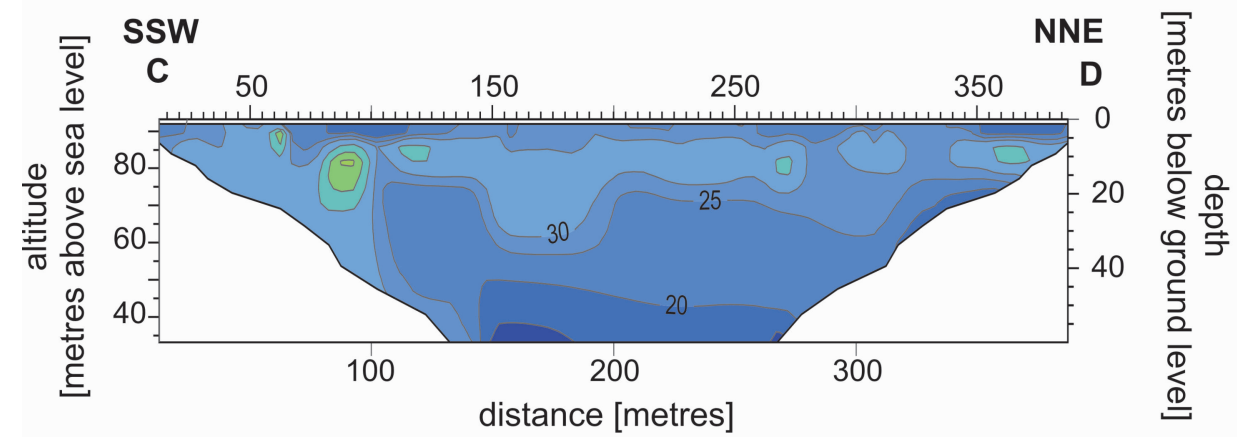

Profile 3
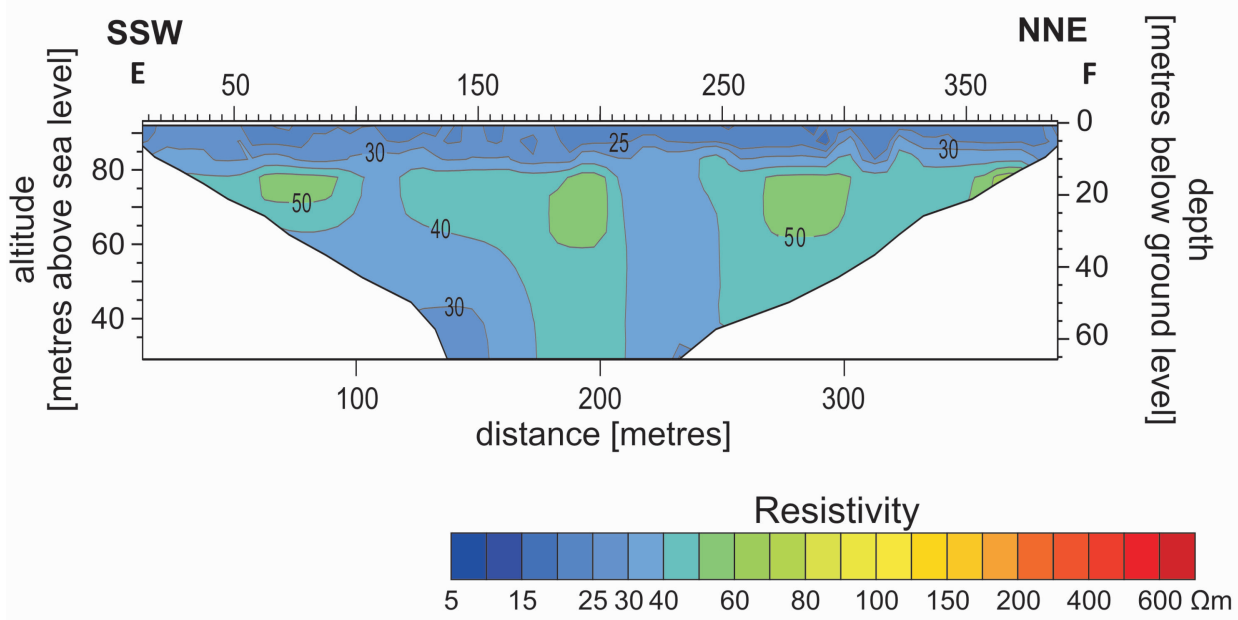

Fig. 6. Resistivity models along profile 1, 2, 3 .

resistivities $(<40 \Omega \mathrm{m})$. The same as in profile 2 , they might be either clays with additive of sediments with higher resistivities as tills or sands or more probably tills or tills with additive of clays. There are three quite wide spots of sediments with higher resistivities $(>40 \Omega \mathrm{m})$. Their upper boundary is located around $10 \mathrm{~m}$ below the surface. They would constitute a continuous layer, if it was not for two, low resistive $(<30 \Omega \mathrm{m})$ sites that stretch from 100 to $120 \mathrm{~m}$ and from 210 to $240 \mathrm{~m}$ and continue downwards. It might be the case that first they were one layer of tills that afterwards was deformed and torn by Pliocene clays due to glacitectonic events. Those results enabled to close the boundary in northeastern part of Kozłowicka buried valley and, in this way, conclude that the valley does not continue northwards (Fig. 5).

Along the profile CVES 1 (Fig. 7), highly resistive com- plex, interpreted as sands, spreads fromthe beginning of the profile to around $560 \mathrm{~m}$ that might be interpreted as SSE boundary of the buried valley. Unfortunately, the NNW boundary was not detected, neither was the trace of sediment with reduced resistivity which would suggest proximity of the boundary. The upper boundary of highly resistive complex was detected at around $80 \mathrm{~m}$ a.s.l. and its bottom boundary - at around $56 \mathrm{~m}$ a.s.l. Underneath, a moderately resistive complex (30-75 $\Omega \mathrm{m})$ was encountered, interpreted either as tills. At around $44 \mathrm{~m}$ a.s.l., low resistive sediments $(<30 \Omega \mathrm{m})$ were detected. They might be interpreted as Pliocene clays.

Highly resistive sediments along the profile CVES 2 were found already around 10 meters below the surface with the bottom boundary around $44 \mathrm{~m}$ a.s.l. in the northwestern part of the profile and at around $50 \mathrm{~m}$ a.s.l. in the southeastern 

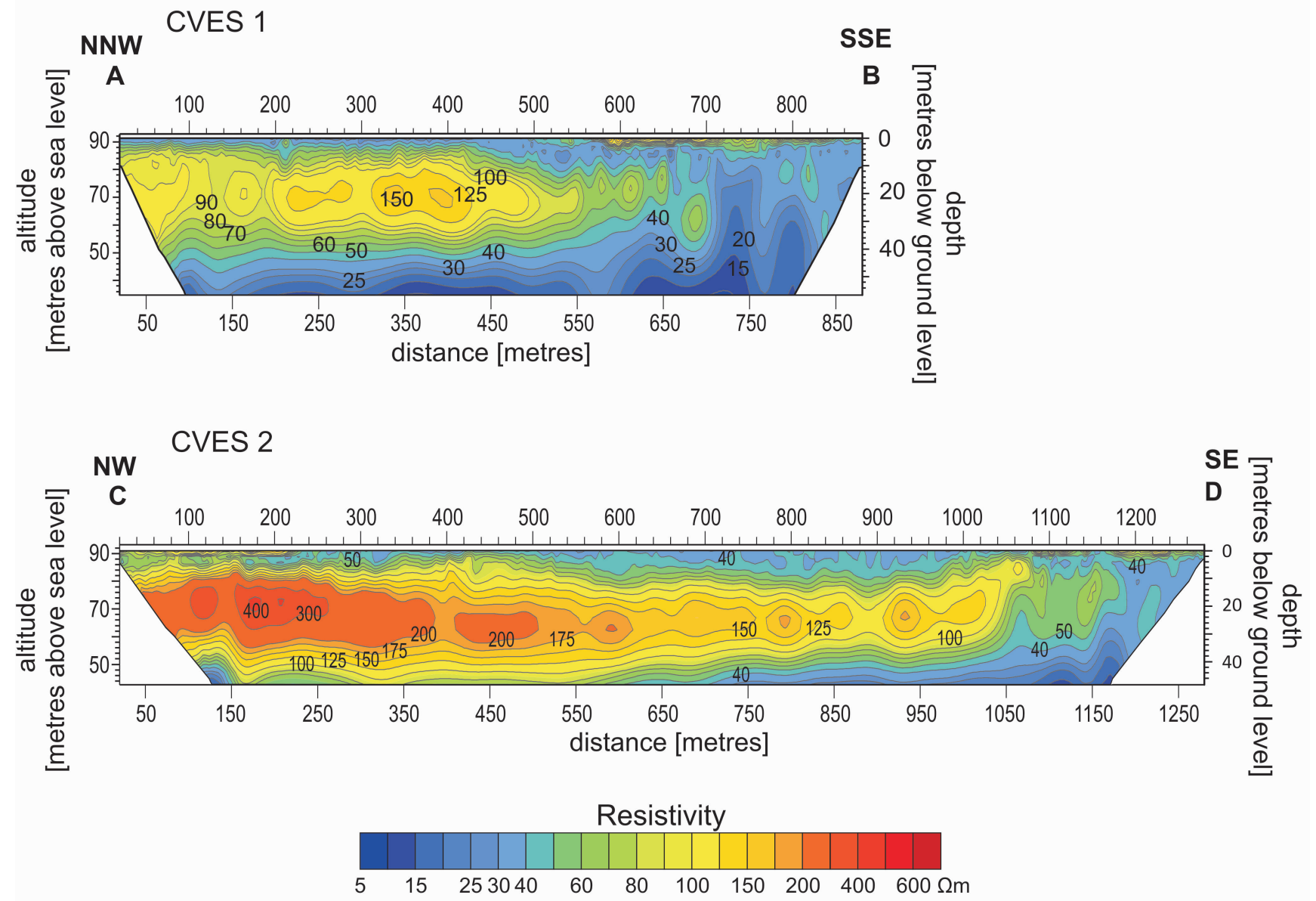

Fig. 7. Resistivity model along CVES 1 and CVES 2 (Topolewska, 2015).In figure 7, two archival resistivity models are presented. Measurements along profiles CVES 1 and CVES 2 were performed in June 2014 and in March 2015. Since they are archival profiles, their color scale does not fully correspond to the color scale of new profiles presented above in figure 6 .

one. Their lateral southeastern border was located at 1080 meters of the profile line. They do not continue eastwards. Northwestern lateral border was not determined, therefore it seems that the valley continues westwards. In order to find out where the buried valley ends, measurement along profile 1 was performed as a part of the research which is described in this paper. Highly resistive sediments of the valley are covered and surrounded by sediments with lower resistvities $(<70 \Omega \mathrm{m})$ which are believed to be tills.

As a result of the new survey, changes in the contour of the upper boundary were made (Fig. 5). In western part, between VES profile lines 9 and 10, the boundary previously was probable, since it could not be confirmed by the profile CVES 2. It was confirmed though by profile 1 and a dashed line (probable contour) was replaced by a continuous one. In northeastern, on the grounds of the results from profile 2 and profile 3 , it was possible to close the structure. The valley does not continue northwards. There is still one part of the northeastern arm of Kozłowicka buried valley where its upper boundary has an unconfirmed contour. In western part (Fig. 5), between VES profile lines 10 and 12, the boundary is conducted with an orange dashed line. It is advisable to perform more ERT measurements in that site in the future.

The results of the new research enabled also to update re- sistivity maps introduced first by Topolewska (2015). The maps (Fig. 8) show how resistivity changes at different altitudes (meters above the sea level) within the northeastern arm of Kozłowicka buried valley. Sections were made every 10 meters from 90 to $30 \mathrm{~m}$ a.s.l. in the form of horizontal planes which sliced the model of the subsurface in a way so that the resistivity distribution at different levels could be seen. They enable first to see changes in resistivity with depth, secondly, to determine location of the bottom of the valley and then to observe denivelation of the bottom. On the maps at 60 and $70 \mathrm{~m}$ a.s.l. continuous structure built of highly resistive sediments is visible. It is surrounded by moderately resistive sediments (around $40 \Omega \mathrm{m}$ ), interpreted as tills. On the maps at 40 and $30 \mathrm{~m}$ a.s.l., under the valley one can see low resistive deposits with resistivities lower than $25 \Omega \mathrm{m}$. They might beinterpreted as Neogene clays. Low resistive sites at altitudes 80 and $90 \mathrm{~m}$ a.s.l. seem not be Neogene clays, since they do not continue on maps at 70 and $60 \mathrm{~m}$ a.s.1. Nevertheless, they can be easily affected by glacitectonic events and then they are hardly distinguishable by resistivity from tills. As we can see, the broadest extent of the valley was captured at $70 \mathrm{~m}$ a.s.1. 


\section{0 m a.s.l.}

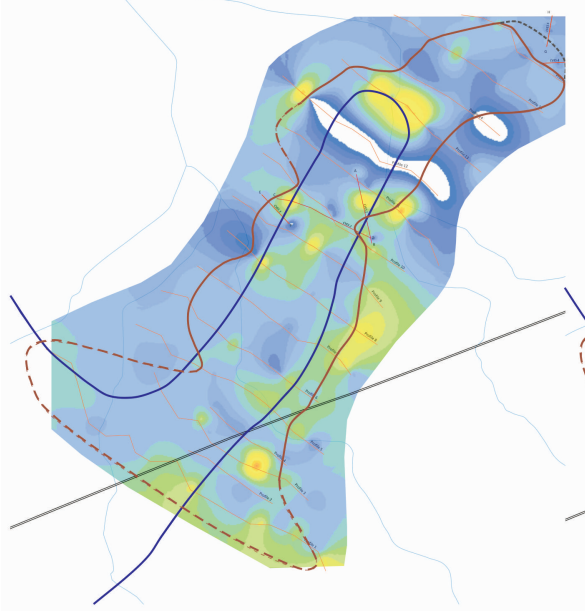

$60 \mathrm{~m}$ a.s.l.
$80 \mathrm{~m}$ a.s.l.

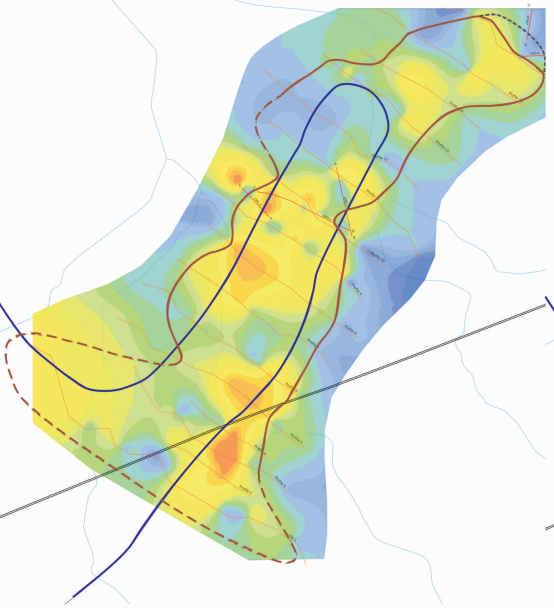

$70 \mathrm{~m}$ a.s.l.

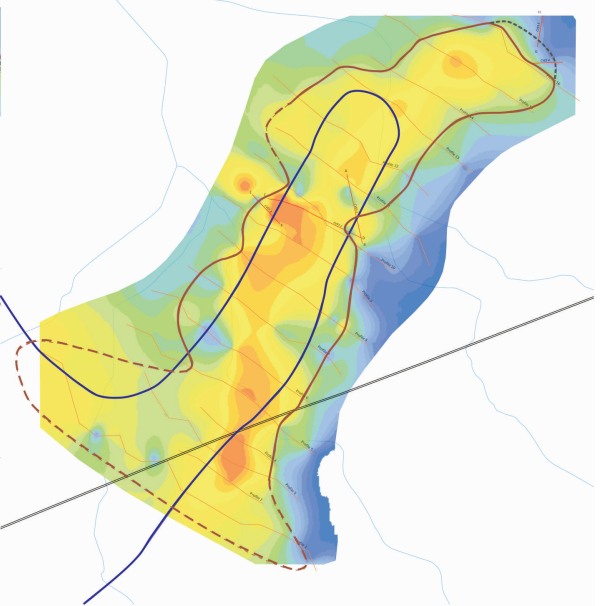

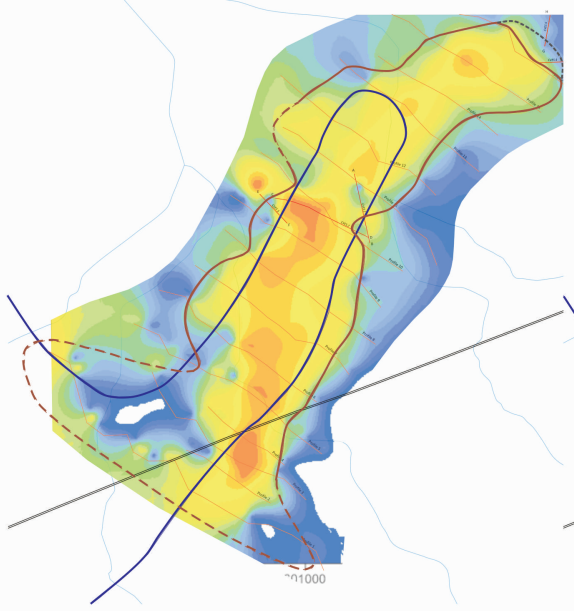

$50 \mathrm{~m}$ a.s.l.

$40 \mathrm{~m}$ a.s.I.
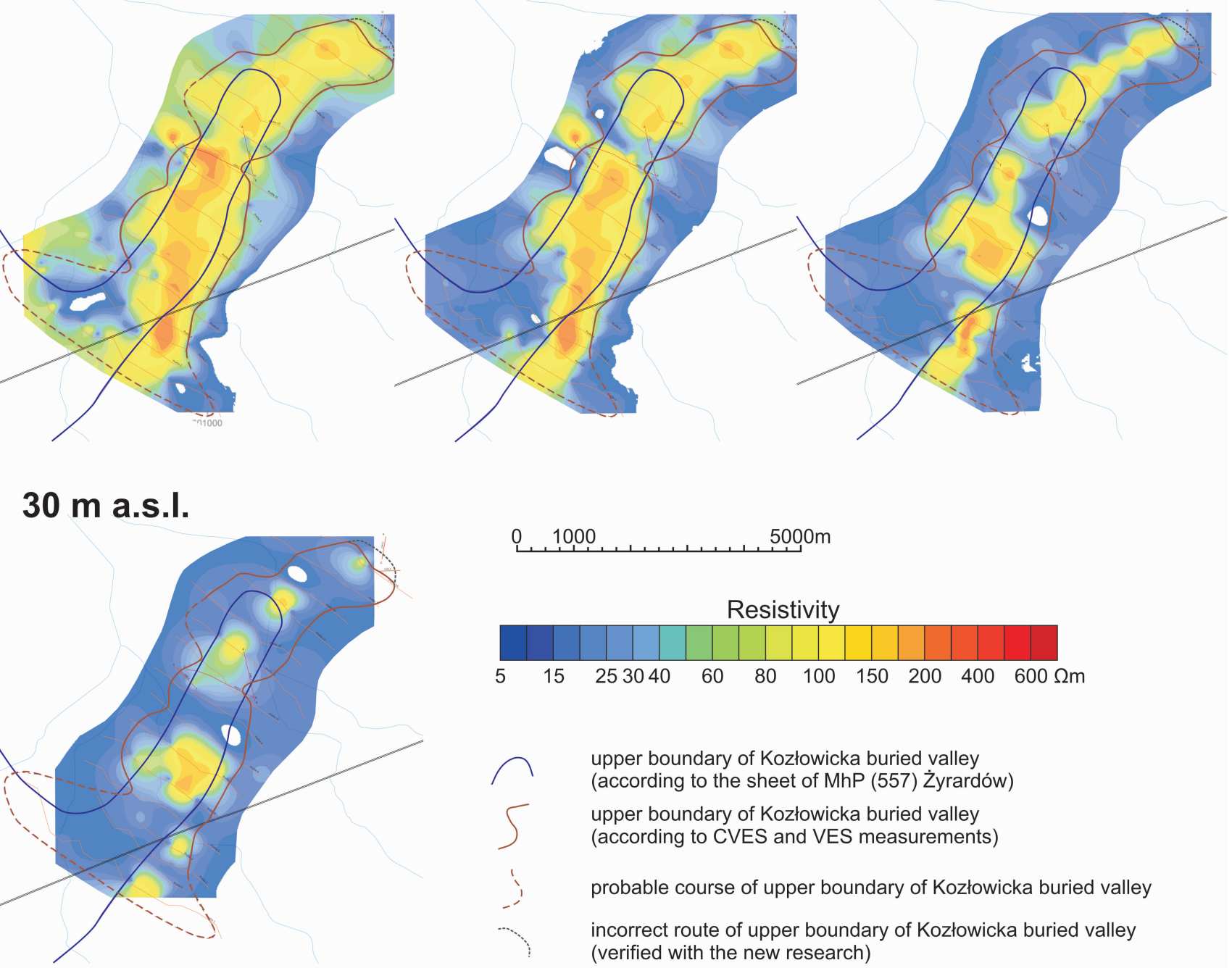

Fig. 8. Resistivity maps at different altitudes above the sea level according to ERT and reinterpreted VES survey (Czerwińska, 1988, Topolewska, 2015) with changes

The maximum extent of the buried valley determinated on the grounds of archival researches (Czerwińska, 1988; Topolewska, 2015) and presented results differs. It might be due to different criteria and ways in which it was determined.
In the article upper boundary of Kozłowicka buried valley corresponds to its maximum extent and was determinated based on resistivity maps at $70 \mathrm{~m}$ above sea level (Fig. 8). 


\section{DISCUSSION}

Geoelectrical measurements are highly recommended in any kind of geological or hydrogeological surveys as a starting point. They provide deeper insight into the substrate and, this way, rough estimation of the shape and extent of the underground structures. Importance of the methods can be seen on the example of MhP. Its quality is of such great relevance, because it is treated as a reference for many different researches. Unspotted mistake may be copied in every following study. The extent of the buried valley was determined by Felter and Nowicki (1998a, b) based on 144 wells situated within $325 \mathrm{~km}^{2}$ of the sheet area. Statistically, there are 2.26 wells per $1 \mathrm{~km}^{2}$. In practice, though, wells were dispersed in a way that most of them were clustered around Żyrardów, located in central part of the sheet. However, such a small amount of wells, in the authors opinion, is not reliable to make further conclusions. In addition, it appears that no existing geoelectrical results were used, since the same geoelectrical researches were taken into account by Topolewska (2015) and completely different results were obtained. The extent of the valley differed. This conclusion was proved in the research described in this paper. That is why broader use of geoeletrical methods is recommended while mapping hydrogeological structures, especially in case of such an extended documentation as MhP. Though geoelectrical measurements in Quaternary sediments are mainly performed as a part of hydrogeological studies (e.g. Binley et al., 2002; Ercoli et al., 2012; Khaki et al., 2016; Mastrocicco et al., 2010), they can be effectively used in order to determine geometry of buried valleys and type of the sediments that fill them up.

\section{REFERENCES}

Ahmad, J., Schmitt, D.R., 2005. Seismic and resistivity imaging for Quaternary channels, Rainbow Lake Northwest Alberta, Canada. CSEG RECORDER 30, 40-43.

Aning, A.A., Sackey, N., Jakalia, I.S., Sedoawu, O., Tetteh, E.H., Hinson, G., Akorlie, R.K., Appiah, D., Quaye, E.K., 2014. Electrical Resistivity as a Geophysical Mapping Tool; A Case Study Of The New Art Department, Knust- Ghana. International Journal of Scientific and Research Publications 4 (1), $1-7$.

Balcerkiewicz, Z., 1989. Hydrogeological documentation of groundwater resources in Quaternary sediments in the region of Żyrardów - Feliksów - Stanisławów (Dokumentacja hydrogeologiczna zasobów wód podziemnych w utworach czwartorzędowych w rejonie Żyrardów - Feliksów - Stanisławów.) Przeds. Produkcji Różnej, Handlu i Usług DEMPOL Poznań (in Polish).

Białostocki, R., Farbisz, J., 2007. Geoelectrical resistivity surveys. Current state and possibilities of taking advantage of the results (Badania geoelektryczne-elektrooporowe. Stan aktualny i możliwości wykorzystania wyników.) Geofizyka. Biuletyn Informacyjny 5, 28-41 (in Polish).

Binley, A., Cassiani, G., Middleton, R., Winship, P., 2002. Vadose zone flow model parameterisation using cross-borehole radar and resistivity imaging. Journal of Hydrology 267, 147-159.

Black, R.A., Frischknecht, F.C., Hazlewood, R.M, Jackson, W.H., 1962. Geophysical methods of exploring for buried channels in the Monument Valley area, Arizona and Utah, Bulletin 1083, $161-288$.
Chongoa, M. Wibroeb, J., Staal-Thomsenb, K., Mosesb, M., Nyambea, I.A., Larsenc, F. Bauer-Gottweinb, P., 2011. The use of Time Domain Electromagnetic method and Continuous Vertical Electrical Sounding to map groundwater salinity in the Barotse sub-basin, Zambia. Physics and Chemistry of the Earth, Parts A/B/C, 36, 14-15, 798-805.

Czerwińska, I., 1988. Documentation of geoelectrical surveys, subject: Water intake - Żyrardów (Dokumentacja badań geoelektrycznych, temat: Ujęcie wody - Żyrardów) (in Polish).

Dahlin, T., 1996. 2D resistivity surveying for environmental and engineering applications. First Break 14 (7), 275-283.

Dahlin, T., Zhou, B., 2006. Multiple-gradient array measurements for multichannel 2D resistivity imaging. Near Surface Geophysics 4 (2), 113-123.

Daily, W., Ramirez, A., Binley, A., LeBrecque, D., 2004. Electrical resistance tomography. The Leading Edge 23(5), 438-442.

Ercoli, M., Pauselli, C., Forte, E., Di Matteo, L., Mazzocca, M., Frigeri, A., Federico C., 2012. A multidisciplinary geological and geophysical approach to define structural and hydrogeological implications of the Molinaccio spring (Spello, Italy). Journal of Applied Geophysics 77, 72-82.

Farbisz, J., Białostocki, R., Zochniak, K., 2010. Geoelectrical resistivity surveys in PBG - yesterday, today and in the coming years (Badania geoelektryczne-elektrooporowe w PBG wczoraj, dziś i w perspektywie najbliższych lat.) Geofizyka, Biuletyn Informacyjny 8, 86-107 (in Polish).

Felter, A., Nowicki, Z., 1998a. Comment to hydrogeological map of Poland 1:50 000, sheet Żyrardów no. 557 (Objaśnienia do Mapy hydrogeologicznej Polski w skali 1:50,000 arkusz Żyrardów (557)) (in Polish).

Felter, A., Nowicki, Z., 1998b. Hydrogeological map of Poland 1:50,000, sheet Żyrardów no. 557 (Mapa hydrogeologiczna Polski w skali 1:50 000 arkusz Żyrardów (557)) (in Polish).

Felter, A., Nowicki, Z., 2003. Groundwater reservoirs in buried Quaternary valleys in the west Mazowsze area. Współczesne Problemy Hydrogeologii. Tom XI, (1), 69-76. Wyd. PGdań. Gdańsk

Herbich, P., Kazimierski, B., Knyszyński, F., Prażak, J., Nowicki, Z., 2007. Subregion Middle Vistula Lowland (Subregion środkowej Wisły nizinny). in: Paczyński, B., Sadurski, A., (Eds.) Regional hydrogeology of Poland (Hydrogeologia Regionalna Polski), t. 1, Freshwater (Wody słodkie), 205-219. Państwowy Insytut Geologiczny. Warszawa (in Polish).

Kemna, A., Kulessa, B., Vereecken, H., 2002. Imaging and characterisation of subsurface solute transport using electrical resistivity tomography (ERT) and equivalent transport models. Journal of Hydrology 267 (3-4), 125-146.

Khaki, M., Yusoff, I., Islami, N., Saboohi, S., 2016. Integrated geoelectrical and hydrogeochemical investigation for mapping the aquifer at Langat Basin, Malaysia. Environmental Earth Sciences 75, 304.

Kondracki, J., 2009. Regional geography of Poland (Geografia regionalna Polski). PWN (in Polish).

Linder, L., Marks, L., 1999. New approach to stratigraphy of palaeolake and glacial sediments of the younger Middle Pleistocene in mid-eastern Poland. Geol. Quart. 43, 1-8.

Lindner, L., Marks, L., 2012. Climatostratigraphic subdivision of the Pleistocene Middle Polish Complex in Poland. Przegląd Geologiczny 60 (1), 36-45.

Loke, M.H., Lane Jr., J.W., 2004. Inversion of data from electrical resistivity imaging surveys in water-covered areas, Explor. Geophys. 35 (4), 266-271.

Loke, M.H., Chambers, J.E., Rucker, D.F., Kuras, O., Wilkinson, P.B., 2013. Recent developments in the direct-current geoelectrical imaging method. Journal of Applied Geophysics 95, 135-156. 
Mastrocicco, M., Vignoli, G., Colombani, N., Zeid, N.A., 2010. Surface electrical resistivity tomography and hydrogeological characterization to constrain groundwater flow modeling in an agricultural field site near Ferrara (Italy). Environmental Earth Sciences 61 (2), 311-322.

Palacky, G.V., 1987. Resistivity characteristics of geologic targets. Electromagnetic methods in applied geophysics. Theory 1, 52-129.

Ratnakumari, Y., Rai, S.N., Thiagarajan, S., Kumar, D., 2012. 2D Electrical resistivity imaging for delineation of deeper aquifers in a part of the Chandrabhaga river basin, Nagpur District, Maharashtra, India. Current science 102 (1), 61-69.

Różycki, S.Z., 1972. Pleistocene of Central Poland in the background of Late Tertiary (Plejstocen Polski Środkowej na tle przeszłości w górnym trzeciorzędzie). PWN. Warszawa (in Polish).

Różycki, S.Z., 1980. Principles of stratigraphic subdivisions of Quaternary of Poland. Quatern. Stud. Pol. 2, 99-106.

Saleh, H., Samsudin, A.R., 2013. Geoelectrical resistivity characterization of sedimentary rocks in Dent Peninsular, Lahad Datu, Sabah. Borneo Science 32, 33-43.

Samouëlian, A., Cousin, I., Tabbagh, A., Bruand, A., Richard, G., 2005. Electrical resistivity survey in soil science: a review. Soil and Tillage Research 83 (2), 173-193.
Smith, E.M., 1974. Exploration for a Buried Valley by Resistivity and Thermal Probe Surveys. Ground Water 12 (2), 78-83.

Smith, R.C., Sjogren, D.B., 2006. An evaluation of electrical resistivity imaging (ERI) in Quaternary sediments, southern Alberta, Canada. Geosphere 2(6), 287-298.

Szalewicz, H., 1993. Detailed Geological Map of Poland in scale 1:50,000, sheet Żyrardów (Szczegółowa mapa geologiczna Polski ark. Żyrardów.)

Topolewska, S., 2015. Hydrogeological mapping of northeastern arm of Kozłowicka buried valley by means of ERT and ves. Master thesis. Faculty of Geology, University of Warsaw.

van Overmeeren, R.A., Ritsema, I.L., 1988. Continuous vertical electrical sounding. First Break 6(10), 313-324.

van Schoor, M., 2002. Detection of sinkholes using 2D electrical resistivity imaging. Journal of Applied Geophysics 50, 393-399.

Wysocki, R., 1996. Annex to the documentation PGK Żyrardów (Aneks do dokumentacji PGK Żyrardów) (in Polish).

Zhou, Q.Y., Shimada, J., Sato, A., 2001. Three-dimensional spatial and temporal monitoring of soil water content using electrical resistivity tomography. Water Resources Research 37, 273286.

Zhou, W., Beck, B.F., Adams, A.L., 2002. Effective electrode array in mapping karst hazards in electrical resistivity tomography. Environ. Geol. 42, 922-928. 